\title{
Reaksi Hidrogenasi Metoksida Menjadi Metanol pada Klaster Pd6Ni
}

\author{
Adhitya Gandaryus Saputro ${ }^{\left.1,2^{*}\right)}$ dan Fiki Taufik Akbar ${ }^{3)}$ \\ ${ }^{1}$ Kelompok Keahlian Teknik Fisika, Fakultas Teknologi Industri, ITB, Jl. Ganesha 10, Bandung 40132, \\ Indonesia. \\ ${ }^{2}$ Pusat Penelitian Nanosains dan Nanoteknologi, ITB, JI. Ganesha 10, Bandung 40132, Indonesia. \\ ${ }^{3}$ Kelompok Keilmuan Fisika Teoretik Energi Tinggi dan Instrumentasi, Fakultas Matematika dan IImu \\ Pengetahuan Alam, ITB, JI. Ganesha 10, Bandung 40132, Indonesia. \\ *Corresponding author: ganda@tf.itb.ac.id
}

\begin{abstract}
ABSTRAK
Kami melakukan kajian teoretis mengenai reaksi hidrogenasi metoksida $\left(\mathrm{H}_{3} \mathrm{CO}\right)$ menjadi metanol $\left(\mathrm{CH}_{3} \mathrm{OH}\right)$ pada katalis klaster $\mathrm{Pd} 6 \mathrm{Ni}$ secara teoretis menggunakan perhitungan berbasis teori fungsional kerapatan (DFT). Reaksi ini merupakan salah satu reaksi pembatas laju pada proses konversi gas karbon dioksida ( $\left.\mathrm{CO}_{2}\right)$ menjadi metanol. Hasil perhitungan kami menunjukkan bahwa reaksi hidrogenasi metoksida pada katalis klaster Pd6Ni memiliki energi aktivasi yang lebih baik dibandingkan dengan energi aktivasi pada katalis konvensional berbasis permukaan $\mathrm{Cu}$. Hal ini disebabkan karena klaster PdoNi mampu menstabilkan adsorpsi molekul metanol dengan baik dan memiliki energi adsorpsi ${ }^{*} H$ yang relatif lemah.
\end{abstract}

Kata kunci : reaksi pembentukan metanol, hidrogenasi metoksida, $\mathrm{Pd} 6 \mathrm{Ni}$, DFT

\section{PENDAHULUAN}

Pemanasan global merupakan salah satu permasalahan serius yang dihadapi dunia saat ini. Sumber utama dari permasalahan ini adalah efek rumah kaca yang disebabkan oleh peningkatan konsentrasi gas $\mathrm{CO}_{2}$ di atmosfer bumi. Konsentrasi gas $\mathrm{CO}_{2}$ di atmosfer bumi telah meningkat secara terus menerus mulai dari $\sim 280$ ppm sebelum revolusi industri, menjadi $\sim 390$ ppm pada 2010 dan diperkirakan akan mencapai $\sim 570$ ppm pada akhir abad ini [1]. Oleh karena itu, perlu dilakukan suatu upaya yang serius untuk mengurangi emisi gas $\mathrm{CO}_{2}$.

Salah satu skema yang mungkin diterapkan untuk mengurangi masalah emisi ini adalah dengan mongkonversi gas $\mathrm{CO}_{2}$ menjadi metanol melalui proses hidrogenasi. Belakangan ini, skema produksi metanol ini menjadi popular di bidang energi alternatif. Metanol merupakan bahan bakar cair praktis yang dapat digunakan untuk mesin pembakaran dalam dan juga untuk sel bahan bakar metanol (direct methanol fuel cell ; DMFC) [2]. Selain itu metanol juga dapat digunakan sebagai sarana penyimpanan gas hidrogen $[3,4]$.

Pada skala industri, selama ini metanol diproduksi menggunakan campuran gas $\mathrm{CO}_{2}$ dan $\mathrm{H}_{2}$ (gas-gas ini diperoleh melalui proses konversi metana gas alam pada temperatur $\sim 850^{\circ} \mathrm{C}$ ) pada tekanan tinggi ( $50-120$ bar) dan pada temperatur $230-280^{\circ} \mathrm{C}$ dengan menggunakan katalis konvensional berbasis $\mathrm{Cu} / \mathrm{ZnO}$ [5]. Sayangnya, persentasi konversi $\mathrm{CO}_{2}$ menjadi metanol pada katalis ini masih kecil dan terbatas secara kinetik pada kisaran 15-25\% [6]. Oleh karena itu, diperlukan pengembangan katalis baru yang dapat meningkatkan persentase konversi gas $\mathrm{CO}_{2}$ menjadi metanol.

Secara keseluruhan, reaksi pembentukan metanol melalui hidrogenasi $\mathrm{CO}_{2}$ bersifat eksotermik. Namun sayangnya, reaksi pembentukan metanol ini tersusun atas beberapa reaksi elementer yang bersifat endotermik dan memiliki energi aktivasi yang besar. Persentase konversi gas $\mathrm{CO}_{2}$ menjadi metanol melalui proses hidrogenasi dapat ditingkatkan apabila katalis yang digunakan dapat menurunkan secara signifikan energi aktivasi dari reaksi-reaksi pembatas laju (rate limiting reaction: rlr) yang terlibat dalam proses ini. Salah satu reaksi pembatas laju utama pada rangkaian reaksi hidrogenasi $\mathrm{CO}_{2}$ menjadi metanol pada permukaan katalis berbasis $\mathrm{Cu}$ adalah reaksi hidrogenasi metoksida $\left(\mathrm{H}_{3} \mathrm{CO}\right)$ menjadi methanol. Reaksi ini bersifat endotermik dan memiliki energi aktivasi yang cukup besar pada permukaan $\mathrm{Cu}(111)\left(E^{a c t}+>=1.17-1.25 \mathrm{eV}\right)[7,8]$. Salah satu cara untuk menurunkan energi aktivasi dari reaksi hidrogenasi $\mathrm{H}{ }_{3} \mathrm{CO}$ ini adalah dengan mencari katalis yang dapat menstabilkan adsorpsi metanol relatif terhadap $\mathrm{H}_{3} \mathrm{CO}$. Dengan demikian, maka profil reaksi hidrogenasi $\mathrm{H}_{3} \mathrm{CO}$ akan menjadi eksotermik sehingga energi aktivasinya juga akan menjadi jauh lebih rendah. 
Pada penelitian ini kami mencoba menggunakan klaster paladium yang didoping dengan nikel $\left(\mathrm{Pd}_{6} \mathrm{Ni}\right)$ sebagai katalis reaksi hidrogenasi $\mathrm{H}_{3} \mathrm{CO}$ menjadi methanol. Pada penelitian sebelumnya, kami menemukan bahwa kluster $\mathrm{Pd}_{6} \mathrm{Ni}$ ini dapat mengikat molekul $\mathrm{CO}_{2}$ dengan cukup kuat (chemisorption) dan dapat memaksa molekul $\mathrm{CO}_{2}$ terikat dengan konfigurasi bidendate [9]. Katalis klaster $\mathrm{Pd}_{6} \mathrm{Ni}$ ini diharapkan dapat menurukan energi aktivasi reaksi hidrogenasi $\mathrm{H}_{3} \mathrm{CO}$ menjadi metanol. Penelitian ini merupakan kajian teoretis yang dilakukan dengan metoda teori fungsional kerapatan.

\section{METODE KOMPUTASI}

Pemodelan reaksi hidrogenasi $\mathrm{H}_{3} \mathrm{CO}$ menjadi metanol pada klaster $\mathrm{Pd} 6 \mathrm{Ni}$ ini dilakukan dengan mengunakan kalkulasi berbasis teori fungsional kerapatan (density functional theory; DFT) $[10,11]$. Perangkat lunak yang digunakan untuk perhitungan DFT adalah Gaussian 09 [12]. Perhitungan energi total dari sistem katalis dilakukan dengan potensial exchange-correlation B3LYP dengan basis set LANL2DZ untuk atom Pd dan basis set $6-311 \mathrm{G}^{* *}$ untuk atom ringan $(\mathrm{C}, \mathrm{O}, \mathrm{H})$.

Struktur optimal dari klaster Pd6Ni ditampilkan pada Gambar 1a. Dalam proses optimasi geometri semua atom pada klaster Pd dibiarkan bergerak bebas. Energi adsorpsi $\left(E_{a d}\right)$ dari suatu molekul dihitung dengan menggunakan persamaan:

$$
E_{a d}=E_{\text {tot }}-\left(E_{\text {mol }}+E_{\text {surf }}\right) .
$$

$E_{\text {tot }}$ merupakan energi total dari sistem adsorpsi, $E_{m o l}$ merupakan energi total dari molekul dan $E_{\text {surf }}$ merupakan energi total dari $\mathrm{Pd} 6 \mathrm{Ni}$. Perhitungan struktur transisi untuk proses hidrogenasi $\mathrm{H}_{3} \mathrm{CO}$ menjadi metanol dilakukan dengan metode synchronous transit-guided quasi-Newton (STQN) [13,14].

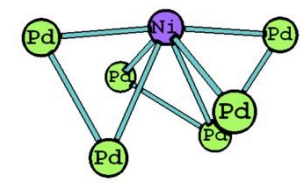

(a)

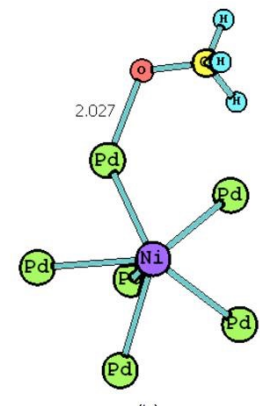

(b)

Gambar 1. Struktur optimal klaster $\mathrm{Pd}_{6} \mathrm{Ni}$ (a) dan adsorpsi $\mathrm{H}_{3} \mathrm{CO}$ pada klaster $\mathrm{Pd} 6 \mathrm{Ni}$ (b).

\section{HASIL DAN PEMBAHASAN}

Geometri optimal dari adsorpsi molekul $\mathrm{H}_{3} \mathrm{CO}$ pada klaster Pd6Ni ditunjukkan pada Gambar $1 \mathrm{~b}$. Atom O dari molekul ${ }^{*} \mathrm{H}_{3} \mathrm{CO}\left({ }^{*} \mathrm{X}\right.$ : atom $X$ terikat pada permukaan katalis) terikat pada salah satu atom $\mathrm{Pd}$ dari klaster $\mathrm{Pd} 6 \mathrm{Ni}$ dengan jarak Pd- O $2.027 \AA$ A. Molekul ini terikat secara kimia melalui interaksi antara orbital$d$ dari klaster $\mathrm{Pd}_{6} \mathrm{Ni}$ dengan orbital- $p$ atom $\mathrm{O}$ dari molekul ${ }^{*} \mathrm{H}_{3} \mathrm{CO}$. Struktur dari klaster $\mathrm{Pd}_{6} \mathrm{Ni}$ mengalami rekonstruksi geometri ketika mengikat molekul $\mathrm{H}_{3} \mathrm{CO}$. Hal ini mengindikasikan bahwa interaksi $\mathrm{Pd}_{6} \mathrm{Ni}$ $\mathrm{H}_{3} \mathrm{CO}$ cukup kuat. Konfigurasi adsorpsi ini mirip dengan struktur adsorpsi $\mathrm{H}_{3} \mathrm{CO}$ di permukaan $\mathrm{Cu}(111)$ $[7,8]$.

Reaksi hidrogenasi ${ }^{*} \mathrm{H}_{3} \mathrm{CO}$ menjadi metanol memerlukan kehadiran setidaknya satu atom $\mathrm{H}$ pada klaster $\mathrm{Pd}_{6} \mathrm{Ni}$. Struktur optimum dari adsorpsi atom $\mathrm{H}$ pada sistem $\mathrm{Pd} 6 \mathrm{Ni}^{-}{ }^{*} \mathrm{H}_{3} \mathrm{CO}$ ditunjukkan pada Gambar 2a. Atom ${ }^{*} \mathrm{H}$ terikat pada situs $\mathrm{Pd}-\mathrm{Pd}$ bridge di dekat situs ${ }^{*} \mathrm{H}_{3} \mathrm{CO}$. Jarak atom ${ }^{*} \mathrm{H}$ ke atom $\mathrm{O}$ dari molekul ${ }^{*} \mathrm{H}_{3} \mathrm{CO}$ adalah $3.686 \AA$. Posisi optimum atom $\mathrm{H}$ yang dekat dengan situs ${ }^{*} \mathrm{H}_{3} \mathrm{CO}$ ini akan sangat membantu proses hidrogenasi menjadi metanol. Apabila jarak ini terlalu jauh, maka dapat dipastikan energi aktivasi yang diperlukan menjadi sangat besar.

Geometri dari kondisi awal (IS), transisi (TS), final (FS) dan energi aktivasi dari reaksi pembentukan metanol melalui hidrogenasi $\mathrm{H}_{3} \mathrm{CO}$ pada klaster $\mathrm{Pd} 6 \mathrm{Ni}$ disajikan pada Gambar 2 dan Tabel 1. Hasil perhitungan kami menunjukkan bahwa energi aktivasi yang diperlukan untuk proses hidrogenasi 
molekul $\mathrm{H}_{3} \mathrm{CO}$ menjadi metanol adalah $0.41 \mathrm{eV}$. Nilai energi aktivasi ini jauh lebih kecil bila dibandingkan dengan nilai energi aktivasi pada katalis klaster $\mathrm{Pd} 7(1.05 \mathrm{eV})$ dan pada katalis konvensional berbasis $\mathrm{Cu}(111)\left(E_{->}^{\text {act }}=1.17-1.25 \mathrm{eV}\right)[7,8]$.

Tabel 1. Energi aktivasi dari reaksi hidrogenasi ${ }^{*} \mathrm{H}_{3} \mathrm{CO}$ pada klaster $\mathrm{Pd} 6 \mathrm{Ni}$. Definisi dari $E^{a c t} t_{l,} E^{\text {act }}{ }_{\forall}$, IS dan FS ditunjukkan pada Gambar 2b.

\begin{tabular}{llccc}
\hline \hline Reaction & Cluster type & $E_{\rightarrow}^{\text {act }}(\mathrm{eV})$ & $E_{\leftarrow}^{\text {act }}(\mathrm{eV})$ & FS-IS (eV) \\
\hline${ }^{*} \mathrm{H}_{3} \mathrm{CO}+{ }^{*} \mathrm{H} \longrightarrow{ }^{*} \mathrm{CH}_{3} \mathrm{OH}$ & $\mathrm{Pd}_{6} \mathrm{Ni}$ & 0.41 & 1.23 & -0.82 \\
\hline \hline
\end{tabular}

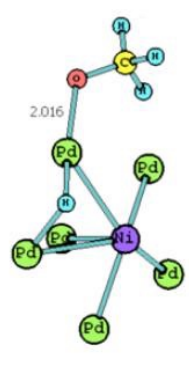

IS

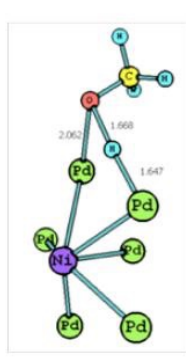

TS

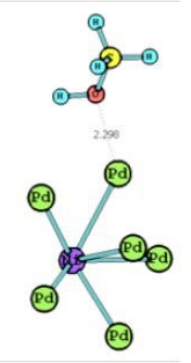

FS

(a)

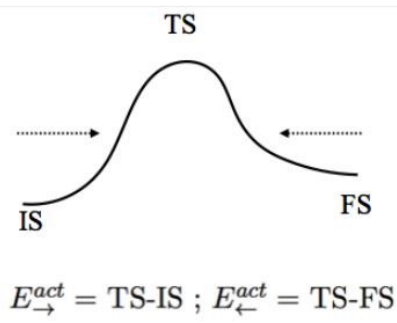

(b)

Gambar 2. Geometri dari kondisi awal (IS: $\left.{ }^{*} \mathrm{H}_{3} \mathrm{CO}+{ }^{*} \mathrm{H}\right)$, transisi (TS: ${ }^{*} \mathrm{H}--\mathrm{H}_{3} \mathrm{CO}$ ) dan kondisi akhir (FS: ${ }^{*} \mathrm{CH}_{3} \mathrm{OH}$ (metanol)) dari proses hidrogenasi $\mathrm{H}_{3} \mathrm{CO}$ di klaster $\mathrm{Pd}_{6} \mathrm{Ni}(\mathrm{a})$. Definisi dari $E^{\text {act }}$ !, $E^{\text {act }}{ }_{\forall}$, IS dan FS (b).

Untuk menjelaskan fenomena ini, kita perlu melihat profil energi dari sistem sebelum dan sesudah terjadi reaksi hidrogenasi. Data energi reaksi (FS-IS) pada Tabel 1 menunjukkan bahwa reaksi hidrogenasi $\mathrm{H}_{3} \mathrm{CO}$ pada klaster Pd memiliki profil eksotermik (melepas energi, bernilai negatif). Hal ini sangat berbeda dengan profil energi reaksi pada katalis $\mathrm{Cu}(111)$ yang memiliki profil endotermik (FS -IS bernilai positif) $[7,8]$. Profil eksotermik inilah yang menyebabkan klaster Pd memiliki energi aktivasi reaksi hidrogenasi $\mathrm{H}_{3} \mathrm{CO}$ pada jauh lebih baik daripada permukaan $\mathrm{Cu}(111)$. Profil eksotermik pada klaster Pd menunjukkan bahwa klaster Pd dapat menstabilkan adsoprsi molekul metanol secara signifikan bila dibandingkan dengan katalis permukaan $\mathrm{Cu}(111)$. Penstabilan adsoprsi molekul metanol ini disebabkan oleh karakter orbital- $d$ dari klaster $\mathrm{Pd}$ yang sangat terlokalisasi bila dibandingkan dengan orbital- $d$ pada permukaan $\mathrm{Cu}(111)$. Karakter orbital- $d$ dari klaster Pd ini memudahkan interkasi dengan orbital molekul dari metanol yang kemudian berakibat pada penstabilan adsorpsi molekul metanol.

Dari struktur TS yang ditunjukkan pada Gambar 2a, dapat dilihat bahwa proses pembentukan metanol perlu melewati satu tahapan penting yaitu desorpsi atom * $\mathrm{H}$ dari $\mathrm{Pd}-\mathrm{Pd}$ bridge menuju atom

O. dari molekul ${ }^{*} \mathrm{H}_{3} \mathrm{CO}$. Energi adsorpsi atom ${ }^{*} \mathrm{H}$ pada klaster $\mathrm{Pd} 6 \mathrm{Ni}(0.44 \mathrm{eV})$ sedikit lebih lemah dibandingkan dengan energi adsorpsi atom ${ }^{*} \mathrm{H}$ pada klaster $\mathrm{Pd} 7(0.45 \mathrm{eV})$. Hal ini menunjukkan bahwa atom ${ }^{*} \mathrm{H}$ di $\mathrm{Pd}-\mathrm{Pd}$ brigde dari klaster $\mathrm{Pd} 6 \mathrm{Ni}$ lebih mudah terdesorpsi sehingga energi aktivasi hidrogenasi 
molekul $\mathrm{H}_{3} \mathrm{CO}$ di klaster ini $(0.41 \mathrm{eV})$ lebih rendah bila dibandingkan dengna energi aktivasi pada klaster $\mathrm{Pd} 7(1.05 \mathrm{eV})$.

Dari diskusi di atas, dapat disimpulkan bahwa klaster $\mathrm{Pd} 6 \mathrm{Ni}$ memiliki energi aktivasi reaksi hidrogenasi $\mathrm{H}_{3} \mathrm{CO}$ yang rendah karena katalis ini mampu menstabilkan adsorpsi molekul metanol dengan baik dan memiliki energi adsorpsi ${ }^{*} \mathrm{H}$ yang relatif lemah

\section{KESIMPULAN}

Kami telah mempelajari reaksi hidrogenasi molekul $\mathrm{H}_{3} \mathrm{CO}$ menjadi metanol pada katalis klaster $\mathrm{Pd} 6 \mathrm{Ni}$ dengan menggunakan perhitungan berbasis teori fungsional kerapatan DFT. Reaksi ini merupakan salah satu reaksi pembatas laju utama (rate limiting reaction) pada proses pembentukan metanol melalui hidrogenasi gas $\mathrm{CO}_{2}$. Hasil perhitungan kami menunjukkan bahwa reaksi hidrogenasi $\mathrm{H}_{3} \mathrm{CO}$ pada katalis klaster $\mathrm{Pd} 6 \mathrm{Ni}$ memiliki energi aktivasi yang lebih baik dibandingkan dengan energi aktivasi pada katalis konvensional berbasis permukaan Cu. Hal ini disebabkan karena katalis ini mampu menstabilkan adsorpsi molekul metanol dengan baik dan mememiliki energi adsorpsi ${ }^{*} \mathrm{H}$ yang relatif lemah. Dua poin ini dapat dijadikan sebagai parameter untuk mendesain katalis baru untuk reaksi hidrogenasi $\mathrm{H}_{3} \mathrm{CO}$ menjadi metanol.

\section{UCAPAN TERIMA KASIH}

Semua kalkulasi dalam penelitian ini dilakukan di fasilitas komputasi Teknik Fisika ITB. AGS dan FTA berterima kasih pada ITB atas bantuan yang diberikan.

\section{DAFTAR PUSTAKA}

[1] X. D. Xu and J. A. Moulijn, Mitigation of $\mathrm{CO}_{2}$ by Chemical Conversion: Plausible Chemical Reactions and Promising Products, Energy Fuels, 1996, 10, 305-325.

[2] Olah G. A., Goeppert A. and Prakash G. K. S., Beyond Oil and Gas: The Methanol Economy, 2nded.; Wiley-VCH: Weinheim, 2009.

[3] M. Nielsen, E. Alberico, W. Baumann, H.-J. Drexler, H. Junge, S. Gladiali and M. Beller, Nature, 2013, 495, 85-89.

[4] K. M. K. Yu, W. Tong, A. West, K. Cheung, T. Li, G. Smith, Y. Guo and S. C. E. Tsang, Nat Commun, 2012, 3, 1230.

[5]Waugh K.C., Methanol Synthesis, Catal.Today 1992,15,51-75.

[6] Liu X. M., Lu G. Q., Yan Z. F., Beltramini, Recent Advances in Catalysts for Methanol Synthesis via Hydrogenation of $\mathrm{CO}$ and CO2, J. Ind. Eng. Chem. Res. 2003, 42, 6518.

[7] Yixiong Yang, Michael G. White, and Ping Liu, Theoretical Study of Methanol Synthesis from $\mathrm{CO}_{2}$ Hydrogenation on Metal-Doped Cu(111) Surfaces, J. Phys. Chem. C, 2012, 116 (1), pp 248- 256.

[8] Grabow L. C. and Mavrikakis M., Mechanism of Methanol Synthesis on Cu through $\mathrm{CO}_{2}$ and $\mathrm{CO}$ Hydrogenation, ACS Catal. 2011, 1, 365-384.

[9] A.G. Saputro, M.K. Agusta, T.D.K. Wungu, Suprijadi, F.Rusydi and H.K.Dipojono,"DFT study of adsorption of $\mathrm{CO}_{2}$ on palladium cluster doped by transition metal" Journal of Physics: Conference Series 739 (2016) 012083.

[10] P. Hohenberg and W. Kohn, Phys. Rev., 1964, 136, B864-B871.

[11] W. Kohn and L. J. Sham, Phys. Rev., 1965, 140, A1133-A1138.

[12] M. J. Frisch, G. W. Trucks, H. B. Schlegel, G. E. Scuseria, M. A. Robb, J. R. Cheeseman, G. Scalmani, V. Barone, B. Mennucci, G. A. Petersson, H. Nakatsuji, M. Caricato, X. Li, H. P. Hratchian, A. F. Izmaylov, J. Bloino, G. Zheng, J. L. Sonnenberg, M. Hada, M. Ehara, K. Toyota, R. Fukuda, J. 
Hasegawa, M. Ishida, T. Nakajima, Y. Honda, O. Kitao, H. Nakai, T. Vreven, J. A. Montgomery, Jr., J. E. Peralta, F. Ogliaro, M. Bearpark, J. J. Heyd, E. Brothers, K. N. Kudin, V. N. Staroverov, R. Kobayashi, J. Normand, K. Raghavachari, A. Rendell, J. C. Burant, S. S. lyengar, J. Tomasi, M. Cossi, N. Rega, J. M. Millam, M. Klene, J. E. Knox, J. B. Cross, V. Bakken, C. Adamo, J. Jaramillo, R. Gomperts, R. E.

Stratmann, O. Yazyev, A. J. Austin, R. Cammi, C. Pomelli, J. W. Ochterski, R. L. Martin, K. Morokuma, V. G. Zakrzewski, G. A. Voth, P. Salvador, J. J. Dannenberg, S. Dapprich, A. D. Daniels, Ö. Farkas, J. B. Foresman, J. V. Ortiz, J. Cioslowski and D. J. Fox, Gaussian09 Revision D.01, Gaussian Inc. Wallingford CT 2009.

[13] C. Peng, P. Y. Ayala, H. B. Schlegel, and M. J. Frisch: J. Comput. Chem.17 (1996) 49.

[14] C. Peng and H. B. Schlegel: Isr. J. Chem. 33 (1994) 449. 